\title{
Wsparcie posłów przez służbę prawną Kancelarii Sejmu w zakresie przygotowywania technicznego projektów ustaw i poprawek do projektów ustaw ${ }^{1}$
}

Obowiązujące rozwiązania prawne wskazują, że zakres merytorycznego wsparcia posłów ze strony Kancelarii Sejmu nie obejmuje działalności legislacyjnej, tj. opracowywania na zlecenie posłów projektów ustaw, a także poprawek do projektów ustaw. Poseł może jednak w sposób pośredni skorzystać ze wsparcia służby prawnej Kancelarii Sejmu, zlecając Biuru Analiz Sejmowych przygotowanie ekspertyzy, której przedmiot będzie odpowiadał planowanym czynnościom legislacyjnym.

Słowa kluczowe: Kancelaria Sejmu, poseł, proces ustawodawczy

Supporting Deputies by the legal service of the Chancellery of the Sejm in the field of technical preparation of bills and amendments: The legal solutions in force indicate that the scope of substantive support provided by the Chancellery of the Sejm does not cover legislative activities, i.e. drafting bills and amendments to bills on behalf of Deputies. However, a Deputy may indirectly benefit from the support of the legal service of the Chancellery of the Sejm by commissioning the Bureau of Research to prepare an expert opinion, the subject of which would correspond to the planned legislative activities.

Keywords: Chancellery of the Sejm, Deputy, legislative process

\section{Przedmiot opinii}

Przedmiotem niniejszej opinii jest odpowiedź na pytanie ,jaki jest zakres uprawnień parlamentarzysty do korzystania ze służb legislacyjnych Kancelarii Sejmu w zakresie przygotowania technicznego projektów ustaw i poprawek do projektów ustaw?".

Opinia prawna w sprawie wsparcia posłów przez służbę prawna Kancelarii Sejmu w zakresie przygotowywania technicznego projektów ustaw i poprawek do projektów ustaw sporządzona 19 lipca 2019 r. na zlecenie posła Klubu Parlamentarnego Prawo i Sprawiedliwość; BAS-WAKiU 1466/19. 


\section{Merytoryczne wsparcie posłów przez Kancelarię Sejmu}

Zgodnie z art. 46 ust. 1 ustawy z 9 maja 1996 r. o wykonywaniu mandatu posła i senatora (t.j. Dz.U. 2018, poz. 1799) Prezydium Sejmu udziela posłom i senatorom pomocy w wykonywaniu przez nich mandatu, czuwa nad wykonywaniem przez nich obowiązków parlamentarnych, jak również nad wykonywaniem wobec nich obowiązków określonych $\mathrm{w}$ ustawie przez organy państwowe i samorządu terytorialnego oraz podporządkowane im jednostki. Z kolei w myśl ust. 2 Kancelaria Sejmu, według swej właściwości, zapewnia i organizuje obsługę posłów i senatorów niezbędną do wykonywania przez nich obowiązków oraz pomoc merytoryczną, zwłaszcza w zakresie dostępu do opracowań specjalistycznych, literatury i ekspertyz. Zadania Kancelarii Sejmu w powyższym zakresie określają szczegółowo regulamin Sejmu oraz uchwały Prezydium Sejmu (ust. 3).

$\mathrm{W}$ przepisach regulaminu Sejmu ${ }^{2}$ kluczowe znaczenie - w kontekście zagadnienia analizowanego w niniejszej opinii - ma art. 12 pkt 6, zgodnie z którym Prezydium Sejmu ustala zasady organizowania doradztwa naukowego na rzecz Sejmu i jego organów, powoływania doradców sejmowych oraz korzystania z opinii i ekspertyz. Na podstawie tego przepisu Prezydium Sejmu wydało (wielokrotnie nowelizowaną) uchwałę nr 28 z 19 kwietnia 1995 r. w sprawie zasad organizowania doradztwa naukowego na rzecz Sejmu i jego organów, powoływania doradców sejmowych oraz korzystania z ekspertyz i opinii. Zgodnie z $\$ 1$ tej uchwały doradztwo naukowe na rzecz Sejmu, jego organów i posłów polega na pozyskiwaniu ekspertów oraz zapewnianiu ekspertyz, opinii lub konsultacji. Ekspertyzy, opinie oraz konsultacje mogą dotyczyć toczących się lub planowanych prac wynikających z funkcji Sejmu i jego organów w zakresie legislacji i działań kontrolnych oraz prac studyjnych (badania, ekspertyzy długofalowe) ( $\$ 3$ ust. 1 uchwały nr 28).

Powyższe przepisy wskazują, że zakres merytorycznego wsparcia posłów ze strony Kancelarii Sejmu nie obejmuje działalności legislacyjnej, tj. opracowywania na zlecenie posłów projektów ustaw, a także poprawek do projektów ustaw. Taki stan rzeczy potwierdzają przepisy regulaminu organizacyjnego Kancelarii Sejmu (stanowiącego załącznik do zarządzenia nr 10 Szefa Kancelarii Sejmu z 25 marca 2002 r., również wielokrotnie nowelizowanego). Regulując szczegółowe zadania dwóch jednostek organizacyjnych Kancelarii Sejmu, które tworzą trzon służby prawnej Kancelarii w rozumieniu przepisów regulaminu Sejmu (zwłaszcza art. 70 ust. 1 regulaminu Sejmu), tj. Biura Analiz Sejmowych ( $\$ 17$ regulaminu organizacyjnego Kancelarii) oraz Biura Legislacyjnego ( $\$ 24$ regulaminu organizacyjnego Kancelarii), nie uwzględniono wśród tych zadań wsparcia legislacyjnego na rzecz posłów. Należy natomiast zauważyć, że zgodnie z $\$ 24$

2 Uchwała Sejmu Rzeczypospolitej Polskiej z 30 lipca 1992 r. - Regulamin Sejmu Rzeczypospolitej Polskiej, M.P. 2012, poz. 32, ze zm. 
ust. 1 pkt 1 regulaminu organizacyjnego Kancelarii do zadań Biura Legislacyjnego należy obsługiwanie komisji i podkomisji sejmowych w zakresie redagowania rozpatrywanych przez te organy projektów aktów prawnych, o których mowa w pkt 1 (tj. projektów ustaw, uchwał, rezolucji, deklaracji, apeli i oświadczeń Sejmu, przed ich skierowaniem do I czytania), poprzez przedstawianie uwag, propozycji i zastrzeżeń - ze szczególnym uwzględnieniem przepisów konstytucyjnych - odnośnie do tekstów tych aktów i zgłoszonych poprawek.

Należy zastrzec, że poseł, który jest zainteresowany podjęciem działań o charakterze legislacyjnym (np. opracowaniem projektu ustawy), może w sposób pośredni skorzystać ze wsparcia służby prawnej Kancelarii Sejmu, zlecając Biuru Analiz Sejmowych przygotowanie ekspertyzy, której przedmiot będzie dotyczył problematyki objętej planowanymi czynnościami legislacyjnymi. Legislacyjne opracowanie projektu poseł musi podejmować bez wsparcia urzędniczego, choćby wykorzystując środki finansowe przekazywane przez Kancelarię Sejmu na funkcjonowanie biura poselskiego. Z kolei posłowie zrzeszeni w kluby mogą dodatkowo korzystać z funduszy przyznawanych biurom tych zrzeszeń parlamentarnych. Warto dodać, że aktualnie przepisy przewidują expressis verbis, iż środki przekazywane (w formie ryczałtowej) na funkcjonowanie tych biur mogą być przeznaczane na wynagrodzenia pracowników tych biur klubów, którzy posiadają wykształcenie prawnicze, a zostali zatrudnieni w celu wspierania działalności klubu poselskiego związanej z procesem tworzenia prawa ( $\$ 8$ pkt 1 zarządzenia nr 8 Marszałka Sejmu z 5 lipca 2005 r. w sprawie warunków organizacyjno-technicznych tworzenia, funkcjonowania i znoszenia biur klubów i kół poselskich).

\section{Przyczyny wyłączenia możliwości świadczenia przez służby prawne Kancelarii Sejmu wsparcia legislacyjnego na rzecz posłów}

Wyłączenie możliwości świadczenia przez służby prawne Kancelarii Sejmu na rzecz posłów wsparcia legislacyjnego, polegającego na opracowywaniu projektów ustaw czy poprawek do projektów ustaw, wynika z dwóch istotnych powodów. Po pierwsze, nałożenie tego typu zadania na służbę prawną Kancelarii Sejmu postawiłoby pracowników tej służby w sytuacji konfliktu interesów, który zapewne prowadziłby do pogorszenia jakości merytorycznego wsparcia Sejmu (jako całej izby bądź jej organów, w szczególności komisji) w wykonywaniu jego konstytutywnej funkcji, tj. funkcji prawodawczej (w szczególności ustawodawczej). Podstawowym zadaniem służby prawnej Kancelarii Sejmu jest bowiem doradztwo w toku procesu legislacyjnego toczącego się w izbie, o czym dobitnie świadczą wspomniane wcześniej wewnętrzne przepisy określające zakres zadań Biura Analiz Sejmowych oraz Biura Legislacyjnego Kancelarii Sejmu, a także powołany już w niniejszej opinii art. 70 ust. 1 regulaminu Sejmu. Zgodnie z tym przepisem w postępowaniu dotyczącym projektów ustaw i uchwał uczestniczy 
przedstawiciel służby prawnej Kancelarii Sejmu, przedstawiając wnioski lub uwagi w zakresie problematyki prawno-legislacyjnej, w tym w sprawie zgodności projektów ustaw z prawem Unii Europejskiej. Wydaje się oczywiste, że w sytuacji, gdyby przedstawiciele służby prawnej najpierw wspierali posłów w tworzeniu projektów czy poprawek od strony legislacyjnej, a następnie uczestniczyli w pracach nad danym projektem, wykonywanie działalności opisanej w przywołanym przepisie mogłoby przybrać charakter pozorny. Przedmiotem oceny byłby bowiem efekt pracy osób dokonujących tej oceny bądź innych osób zatrudnionych w służbie prawnej Kancelarii Sejmu.

Po drugie, należy wziąć po uwagę fakt, że nawet jeśli udałoby się ograniczyć owo wsparcie do kwestii stricte technicznych ( $\mathrm{tj}$. odzwierciedlania w projektowanych przepisach zamysłu legislacyjnego przyświecającego danemu posłowi), co mogłoby okazać się trudne do wykonania, to wydaje się bezsporne, iż wspierający posła legislator mógłby być postrzegany jako współautor danego projektu czy poprawki. Taki stan rzeczy mógłby podawać w wątpliwość ciążący na pracownikach Kancelarii Sejmu nakaz zachowania bezstronności (neutralności politycznej). Należy pamiętać, że zgodnie z art. 17 ust. 2 pkt 4 ustawy z 16 września 1982 r. o pracownikach urzędów państwowych (t.j. Dz.U. 2018, poz. 1915, ze zm.), regulującej w podstawowym zakresie status prawny pracowników Kancelarii Sejmu, urzędnik państwowy obowiązany jest m.in. bezstronnie wykonywać powierzone mu zadania. $Z$ wymogiem tym koresponduje nakaz zawarty w art. 19 ust. 2 powołanej ustawy. Przepis ten stanowi, że urzędnik państwowy nie może wykonywać zajęć, które pozostawałyby w sprzeczności z jego obowiązkami albo mogłyby wywołać podejrzenie o stronniczość lub interesowność.

\section{Podsumowanie}

- Obowiązujące rozwiązania prawne wskazują, że zakres merytorycznego wsparcia posłów ze strony Kancelarii Sejmu nie obejmuje działalności legislacyjnej, tj. opracowywania na zlecenie posłów projektów ustaw, a także poprawek do projektów ustaw. Poseł, który jest zainteresowany podjęciem działań o charakterze legislacyjnym (np. opracowaniem projektu ustawy), może jednak w sposób pośredni skorzystać ze wsparcia służby prawnej Kancelarii Sejmu, zlecając Biuru Analiz Sejmowych przygotowanie ekspertyzy, której przedmiot będzie odpowiadał planowanym czynnościom legislacyjnym.

- Wyłączenie możliwości świadczenia przez służby prawne Kancelarii Sejmu na rzecz posłów wsparcia legislacyjnego, polegającego na opracowywaniu projektów ustaw czy poprawek do projektów ustaw, wynika z dwóch powodów.

Po pierwsze, nałożenie tego typu zadania postawiłoby pracowników tej służby prawnej w sytuacji konfliktu interesów. Statutowym zadaniem służby prawnej Kancelarii Sejmu jest bowiem doradztwo w toku procesu legislacyjnego to- 
czącego się w izbie. W sytuacji, gdyby przedstawiciele służby prawnej najpierw wspierali posłów w tworzeniu projektów czy poprawek od strony legislacyjnej, a następnie świadczyli doradztwo w pracach nad danym projektem, przedmiotem doradztwa byłby efekt pracy tych osób (bądź innych osób zatrudnionych w służbie prawnej Kancelarii Sejmu).

Po drugie, legislator wspierający posła w czynnościach legislacyjnych zapewne byłby postrzegany jako współautor danego projektu czy poprawki, co mogłoby podawać w wątpliwość ciążący na pracownikach Kancelarii Sejmu obowiązek zachowania bezstronności. 